\title{
Hematology Profile Analysis and Birth Weight in Preeclampsia
}

\author{
Listyaning Eko Martanti*, Dhita Aulia Octaviani, Ida Ariyanti, Prasko Prasko, Friska \\ Adiani \\ Department of Midwifery, Poltekkes Kemenkes Semarang, Semarang - Indonesia
}

\begin{abstract}
Preeclampsia is a specific syndrome in pregnancy that occur after 20 weeks gestation in women who were previously normotensive. Hypertension in pregnancy caused complications in cardiovascular, hematology, endocrine, metabolic and regional blood flow accompanied by disorders of various organs, resulting in an increase of hemoconcentration in haemoglobin. The purpose of this study was to analyze the hematology profile and birth weight in preeclampsia. the design of this study was cross sectional with a sample of 40 respondents, consisting of 20 preeclampsia women and 20 women normal pregnancy. The hematology profile assessed was haemoglobin levels, hematocrit levels, platelet levels and blood sedimentation rates. The results showed haemoglobin levels, hematocrit levels, platelet level and blood sedimentation rates in both groups were not significantly difference with $\mathrm{p}$ value in each category was 0,$110 ; 0,163$; 0,686 and 0,983 ( $\mathrm{p}$ value $>0,05$ ). Thus this study concludes that the hematological profile and birth weight in preeclampsia and normal pregnancies are the same.
\end{abstract}

Keywords. hematological profile; preeclampsia; birth weight.

\section{Introduction}

Preeclampsia in pregnancy is characterized by hypertension after 20 weeks gestation, followed by one of the criteria namely: proteinuria, organ dysfunction and uteroplacental dysfunction [1]. In the world there are estimated 349.000 women dying during pregnancy or childbirth and preeclampsia is the second cause of maternal death [2].

The clinical finding of preeclampsia can manifest either as a maternal syndrome (hypertension, proteinuria with or without edema and other multisystem abnormalities) or as a foetal syndrome (foetal growth restriction, reduced amniotic fluid and abnormal placentation) [3].

The sole source of nutrients for the growing foetus is the maternal blood [4]. The pathogenesis of preeclampsia is accumulation of the fibrinoid material and foam cells in spiral arteries caused by trophoblastic invasion which lead to reduced blood flow and

\footnotetext{
*Corresponding author: listy@poltekkes-smg.ac.id
} 
favour the interaction between the surrounding cells. Longer exposure of red blood cells to oxygen metabolites and proteases produced by inflammatory cells causes red blood cells damage which may compromise maternal foetal exchange of oxygen and hence alters placental homeostatis and foetus development [5].

Clinical research showed that preeclampsia significantly caused low birth weight [5]. Low birth weight in babies born with preeclampsia occurred because babies are born premature or mature but have growth restriction caused by retropalsenter circulation disorder whereas arteriola spasm causes asphyxia and longer spasm can interfere foetal growth. Arteriola spasm causes blood flow constriction to retroplacenta which interfere with exchanges of $\mathrm{CO} 2, \mathrm{O} 2$ and nutrients in foetus, thus impact foetal growth restriction $[7,8]$.

It is caused by various changes in pregnancy, one of its is hematology changes of pregnant women. ${ }^{9}$ So as to detect preeclampsia, in addition to blood pressure and proteinuria, hematology profile is one thing that worth for researching [5]. According to recent reports, the levels of haemoglobin can help to predict preeclampsia [10-13]. In addition, other researchers, showed that high levels of haemoglobin may be associated with the increased risk of diabetes, hypertension in pregnancy, preterm delivery and low birth weight [12].

In addition to haemoglobin levels, hematocrit levels in preeclampsia are also higher that in normal pregnancy [13]. High hematocrit levels or low blood plasma volume during pregnancy, especially in second trimester can be associated with the risk of foetal growth restriction, foetal death, preterm labor and preeclampsia [13].

Another research also revealed a decrease in platelet levels and an increase in the rate of blood sedimentation in preeclampsia occurs due to arteries vasospasm that causes trombositopenia $[14,15]$.

Based on previous researchers hematology profile in preeclampsia is needed to be assess to known whether or not in every preeclampsia occurs hematological changes or can we used hematology profile in pregnancy as an indicator to detect preeclampsia and also its effect in baby birth weight. The different of this research with previous researchers was 4 category of profile hematology (haemoglobin levels, hematocrit levels, platelet levels and blood sedimentation rates) that being assess, also place and time occurrence of preeclampsia. This research aims to determine whether the hematology profile (haemoglobin levels, hematocrit levels, platelet levels, and blood sedimentation rates) can be used as an indicator to predict preeclampsia and to compare birth weight of preeclampsia and normal pregnancy.

\section{Research Method}

This research is a cross sectional study conducted in august until September 2019 in 9 public health center of Semarang city, namely Bulu Lor, Halmahera, Kedungmundu, Genuk, Bangetayu, Tlogosari Wetan, Tlogosari Kulon, Ngesrep and Sekaran whose implementation is assisted by 2 enumerators with a midwifery undergraduate degree background.

The population in this research were all third trimester pregnant women in 9 public health center of Semarang city and the data were obtained through antenatal care history record. With convenient sampling (non probability sampling), a total of 40 respondents were obtained.

In this research the sample was divided into 2 groups, namely 20 respondents with preeclampsia (third trimester pregnant women with blood pressure $\geq 140 / 90 \mathrm{mmHg}$ and proteinuria +1 ) and 20 respondents with normal pregnancy (third trimester pregnant women with blood pressure normotensive and proteinuria negative) that meets the 
research's inclusion and exclusion criteria. Each respondent was asked to fill out an informed consent sheet and a blood sample was taken one times for each respondents in third trimester pregnancy.

Blood taken was as much as 2,5 cc and put into EDTA tubes for blood hematology examination namely haemoglobin levels, hematocrit levels, platelet levels and blood sedimentation rates which were analyzed by IBL Laboratory in Semarang. Data of birth weight are obtained through birth records.

After normality test, the blood hematology profile (hematocrit levels, platelet levels and blood sedimentation rates) and birth weight were analyzed using an independent t-test while haemoglobin levels were analyzed using Mann Whitney test.

This research was approved by the ethics commission of Sultan Agung Islamic University in Semarang with number 336/VIII/2019/KomisiBioetik.

\section{Analysis Results}

Table 1 shows that the mean ages in preeclampsia was 30,7 years and 29,7 years in non preeclampsia. Mean haemoglobin levels was $11.61 \mathrm{gr} / \mathrm{dl}$ in preeclampsia and $11.05 \mathrm{gr} / \mathrm{dl}$ in non preeclampsia. Mean hematocrit levels was $34.85 \%$ in preeclampsia and $33.10 \%$ in non preeclampsia. Mean platelet levels was $281.9 \times 10^{3} / \mu \mathrm{L}$ in preeclampsia and $292.5 \times 10^{3} / \mu \mathrm{L}$ in non preeclampsia. Mean blood sedimentation rates was $37 \mathrm{~mm} /$ hours in preeclampsia and 36.9 in non preeclampsia. Mean birth weight was $3250 \mathrm{gr}$ in preeclampsia and $3225 \mathrm{gr}$ in non preeclampsia.

.Table 1. frequency distribution of ages, haemoglobin levels, hematocrit levels, platelet levels, blood sedimentation rates and birth weight in preeclampsia.

\begin{tabular}{lccccc}
\hline \multicolumn{1}{c}{ Variables } & Mean & Median & Min & Max & SD \\
\hline Ages & & & & & \\
Preeclampsia & 30.7 & 30.5 & 24 & 40 & 4.231 \\
Non Preeclampsia & 29.7 & 28.5 & 22 & 39 & 5.833 \\
\hline Haemoglobin levels & & & & & \\
Preeclampsia & 11.61 & 11.65 & 9 & 14 & 1.315 \\
Non Preeclampsia & 11.05 & 10.65 & 10 & 14 & 1.278 \\
\hline Hematocrit levels & & & & & \\
Preeclampsia & 34.85 & 35 & 27 & 41 & 3.964 \\
Non Preeclampsia & 33.10 & 32 & 28 & 43 & 3.810 \\
\hline Platelet levels & & & & & \\
Preeclampsia & 281.9 & 268 & 150 & 437 & 87.7 \\
Non Preeclampsia & 292.5 & 288 & 175 & 450 & 76.6 \\
\hline Blood sedimentation & & & & & \\
rates & 37 & 39.5 & 6 & 65 & 18.48 \\
Preeclampsia & 36.9 & 30 & 5 & 78 & 24.17 \\
Non Preeclampsia & & & & & \\
\hline Birth weight & 3083.50 & 3250 & 2100 & 3800 & 491.97 \\
Preeclampsia & 3190.50 & 3225 & 2570 & 3800 & 306.05 \\
Non Preeclampsia & 7073.31 & 7278.8 & 5126 & 8821 & 21435.97 \\
\hline Total &
\end{tabular}

Table 2 shows that all variable (ages, haemoglobin levels, hematocrit levels, platelet levels, blood sedimentation rates and birth weight) was normally distributed in preeclampsia group ( $\mathrm{p}$ value $<0,05$ ), while in non preeclampsia group haemoglobin levels 
was not normally distributed ( $\mathrm{p}$ value $>0,05$ ).

Table 2. Normality data

\begin{tabular}{|l|c|c|}
\hline \multirow{2}{*}{\multicolumn{1}{c|}{ Variables }} & \multicolumn{2}{c|}{$p$-value } \\
\cline { 2 - 3 } & Preeclampsia & Non preeclampsia \\
\hline Ages & 0.305 & 0.105 \\
\hline Hemoglobin levels & 0.221 & 0.046 \\
\hline Hematocrit levels & 0.106 & 0.059 \\
\hline Platelet levels & 0.351 & 0.583 \\
\hline Blood sedimentation rates & 0.230 & 0.068 \\
\hline Birth weight & 0.139 & 0.935 \\
\hline
\end{tabular}

Table 3 shows that there is no significant difference ages in both groups with $\mathrm{p}$ value $>$ $0,05(0,519)$. Haemoglobin levels in both groups are not significantly difference ( $\mathrm{p}$ value $=$ $0,519)$, hematocrit levels in both groups are not significantly difference ( $p$ value $=0,163)$, platelet levels in both groups are not significantly difference ( $p$ value $=0,686$ ), blood sedimentation rates in both groups are not significantly difference $(\mathrm{p}$ value $=0,983)$, birth weight in both groups are not significantly difference $(\mathrm{p}$ value $=0.414)$.

Table 3. The differences of ages, hemoglobin levels, hematocrit levels, platelet levels, blood sedimentation rates and birth weight in preeclampsia

\begin{tabular}{lccc}
\hline \multicolumn{1}{c}{ Variables } & Preeclampsia & Non preeclampsia & $P$ \\
\hline ages (years) & & & \\
Mean & $30.7(4.231)$ & $29.7(5.833)$ & 0.519 \\
Median & 30.5 & 28.5 & \\
Minimum & 24 & 22 & \\
Maximum & 40 & 39 & 0.110 \\
Haemoglobin & & & \\
levels (g/dl) & $11.61(1.315)$ & $11.05(1.278)$ & \\
Mean & 11.65 & 10.65 & \\
Median & 9 & 10 & 0.163 \\
Minimum & 14 & 14 & \\
Maximum & & & \\
Hematocrit & & $33.10(3.810)$ & \\
levels (\%) & $34.85(3.964)$ & 32 & \\
Mean & 35 & 43 & \\
Median & 27 & & \\
Minimum & 41 & & \\
Maximum & & & \\
\hline Platel lev & & & \\
\hline
\end{tabular}

Platelet levels

(X $\left.10^{3} / \mu \mathrm{L}\right)$

\begin{tabular}{lccc} 
Mean & $281.9(87.7)$ & $292.5(76.6)$ & 0.686 \\
Median & 268 & 288 & \\
Minimum & 150 & 175 & \\
Maximum & 437 & 450 & \\
\hline
\end{tabular}

\section{Blood}

sedimentation

rates

(mm/hours) 


\begin{tabular}{lccc} 
Mean & $37(18.48)$ & $36.9(24.17)$ & 0.983 \\
Median & 39.5 & 30 & \\
Minimum & 6 & 5 & \\
Maximum & 65 & 78 & \\
\hline Birth weight & & & \\
(gr) & & 3190.50 & 0.414 \\
Mean & $30383.50(35,05)$ & 3225 & \\
Median & 3250 & 2570 & \\
Minimum & 2100 & 3800 & \\
Maximum & 3800 &
\end{tabular}

\section{Hematology profile in preeclampsia}

Based on research that has been done, haemoglobin levels in preeclampsia was higher than non preeclampsia, but not significantly difference $(\mathrm{p}$ value $=0,519)$, means that haemoglobin levels in both groups are the same. This results was different with the research of phaloprakan et.al and Chang et. al which concluded that haemoglobin levels was higher in first and third trimester can be associated with preeclampsia $(p>0,01)$ or the research of Nasiri $M$, et al which showed that in preeclampsia, haemoglobin levels was higher compared with normotensive whereas mean haemoglobin levels in first trimester was higher than second trimester and lower than third trimester with $p$ value $<0,001$ thus haemoglobin levels can be used as one of indicator of preeclampsia [17].

But with this research we concluded that haemoglobin levels cannot be use as a define indicator of preeclampsia but as a early sign of preeklampsia, whereas blood pressure, proteinurine, or other blood profile still need to be assessed.

This research showed that in preeclampsia hematocrit levels was $34.85 \%$, higher than non preeclampsia $33,10 \%$, but not significantly difference ( $\mathrm{p}$ value $=0,163$ ). This result was difference with the research of Basak et al, and also the research of Heilman which concluded there is an increase of hematocrit levels in preeclampsia compare to normotensive $[13,18]$.

Other research also showed that there is a significant correlation between hematocrit and gestation [19]. But in this research hematocrit levels in both group was founded to be not significantly difference, so we can concluded that hematocrit levels in preeclampsia was higher than non preeclampsia but this is not always happen in every pregnancy women and hematocrit levels cannot be used as a define indicator of preeclampsia.

In this research, platelet levels in preeclampsia was lower than non preeclampsia but not significantly difference ( $\mathrm{p}$ value $>0,05$ ). This is different with the research of Jaremo et al that founded in preeclampsia there is a significant decreased of platelet levels. ${ }^{21}$ however this result was in line with the research of Ceyhan et al which assess hematology profile of 56 preeclampsia and 43 normal pregnancy women which founded there is significant difference in platelet levels of both groups [21]. So we can concluded that platelet levels cannot be use as a define indicator of preeclampsia.

Blood sedimentation rates in this research was $37 \mathrm{~mm} /$ hours in preeclampsia and higher than non preeclampsia but not significantly difference ( $p$ value $>0,05$ ). The research of Van $\mathrm{NR}$ et al showed that blood sedimentation rate was affected by gestation and hemoglobin levels with $\mathrm{p}$ value $<0,0001$. Also in third trimester founded that normal blood sedimentation rates was $15-116 \mathrm{~mm} /$ hours so the result of this research was still in category normal therefore an increase of blood sedimentation rates cannot be used as an define indicator of preeclampsia [22].

\section{Effect of Preeclampsia in Birth Weight}

This research showed that there is no significant difference in birth weight between both 
groups ( $\mathrm{p}$ value $>0,05$ ). This result was different with other researchs which concluded that in preeclampsia mean birth weight was lower than non preeclampsia in every gestation [23].

This is happen because in this research we are not assess other factor that affect baby birth weight and based on research of Seyom E et al social economic status, gestation, and blood pressure during pregnancy affect baby birth weight [23, 24].

Levels of severity and occurrence time of preeclampsia was also affect baby birth weight. The research of Odeagrd RA et al founded that preeclampsia in early pregnancy have a significant effect in fetal growth restriction. This research also said that low birth weight risk also have higher occurrence [6].

Based on our research we can concluded that there is no significant diffence in hematology profile (hemoglobin levels, hematocrit levels, platelet levels and blood sedimentation rates) in preeclampsia and non preeclampsia so we can assumed that plasenta dysfunction not occurs therefore there is no foetal growth restriction which affect baby birth weight. This is in line with the research of Obed SA that concluded preeclampsia is a heterogenic disorder which causes 2 phases, baby born with normal weight (normal placenta) and low birth weight baby (placenta dysfunction) [25].

Further research about level severity of preeclampsia, occurance time of preeclampsia (in first, second or third trimester) and its effect on baby birth weight is needs to be researched.

\section{Conclusion}

In preeclampsia hematology changes may not be occurs, thus hematology profile cannot be used as a define indicator of preeclampsia. Whereas baby birth weight in preeclampsia and non preeclampsia also not significantly difference.

\section{References}

[1] Ramos JGL, Sass N, and Costa SHM. Preeclampsia. Rev Bras Ginecol Obstet. (2017); 39-496-512

[2] Say L and Alkema L. Global Causes of Maternal Death: a WHO Systematic Analysis

[3] Gawde A, UT Bhosale. A study of maternal and perinatal outcome in preeclampsia. International Journal of Recent Trends in Science and Technology. (2014); vol 10, issue 2

[4] Babay ZA, Addar MH, Warsy AS, El-Hazmin MA. The inter-relationship hematologival parameters between Saudi newborns and parents Saudi. Med J. (2002); vol 23(8); 943-6

[5] Catarino C, Rebelo I, Belo L, Rocha-pereira P, Rocha S, Catro EB, et al. Erythrocyte Damage/aging/removal are Enhanched in both mother and foetus in preeclampsia. Actas Bioq. (2008); $9: 63-67$

[6] Odegard RA, Vatten LJ, Nilsen ST, Salvesen KA, Austgulen R. Preeclampsia and fetal growth. Obstet Gynecol. 2000 Dec; 96(6): 950-5

[7] Cunningham,F.G., et al, (2006). Obstetri william, Edisi 21, EGC, Jakarta.

[8] Gilbert, E.S., \& Harmon, J.S. (2005) Manual of high risk pregnancy and delivery. (Third Edition). St.Louis: Mosby.

[9] Manuaba IBG, Manuaba IAC, Manuaba IBGF. Hipertensi dalam kehamilan. In: Astuti NZ, Purba DI, Handayani S, Damayanti R, editor. Pengantar Kuliah Obstetri. Jakarta: Penerbit Buku Kedokteran EGC; (2007):401-17.

[10] Phaloprakarn C, Tangjitgamol S. Impact of high maternal hemoglobin at first 
antenatal visit on pregnancy outcomes: a cohort strudy. J Perinat Med. (2008);36(2): $115-9$

[11] Von Tempelhoff GF, Heilmann L, Rudig L, Pollow K, Hommel G, Koscielny J. Mean maternal second-trimester hemoglobin concentration and outcome of pregnancy: a population-based study. Clin Appl Thromb Hemost. (2008);14(1): 19-28

[12] Laflamme Em. Maternal hemoglobin concentration and pregnancy outcome: a study of the effecys of elevation in el alto, bolivia. Mcgill J Med. (2011); 13(1):47

[13] Heilman L, Gerhold S, Tempelhoff GFV, Pollow K. The role of intravenous volume expansion in moderate preeclampsia. Clin. Hemorheol. (2001);25:83-89

[14] Phibbs, Roderic H. Phatofisiology of Intrapartum asfiksia and resuscitation in Avery Gordon B, Fletcher May Ann, Mac Donald Mhairi G. Neonatology Pathophysiology and Management of the Newborn 4th ed. Philadelphia: JB.Lippincott Co; 248-251.

[15] Utami, Ayu RP, Puspitasari RD, Graharti R. Indeks trombosit pada penderita preeklampsia di RSUD DR. H. Abdul Moeloek, Provinsi Lampung. JK Unila. (2018); vol 2:102-106

[16] Chans SC, O’Brien KO, Nathanson MS< Mancini J, Witter FR. Hemoglobin concetrations influence birth outcomes in prengnant African-American adolescents. J Nutr. (2003); 133(7): 2348-55

[17] Nasiri M, Faghihzadeh S, Alavi M, Zayeri F, Kariman et al. Longitudinal discriminant analysis of hemoglobin level for predicting preeclampsia. Iran Red Crescent Med J. (2015); 17(3) e19489

[18] Basak SK, Begum K, Rashid M, Yasmin N, Begum H. Haematocrit value in preeclampsia. Bangladesh J Obstet Gynaecol, (2015); vol. 30 (2): 80-85

[19] Khoigani MG, Goli S, Zadeh AH. The relationship of hemoglobin and hematocrit in the first and second half of pregnancy with pregnancy outcome.

[20] Jaremo P, Lindahl TL, Lennmarken C, Forsgren H. the use of platelet density and volume measurements to estimate the severity of pre- eclampsia. Eur J Clin Invest (2000); 30: 1113-8

[21] Ceyhan T, Beyan C, Baser I, Kaptan K, Gungor S, Irfan A. the effect of pre-eclapmsia on complete blood count, platelet count and mean platelet volume. Ann hematol (2006); 85-320-2

[22] Van den Broek NR and Letsky EA. Pregnancy and the erythrocyte sedimentation rate. BJOG: an international journal of obstetrics \& gynaecology. (2008). vol. 108: issue 11

[23] Seyom E, Abera $M$ et al. Maternal and fetal outcome of pregnancy related hypertension in Mettu Karl Referral Hospital, Ethiopia. Journal of ovarian research. (2015). 10

[24] Aabidha PM, Cherian AG et al. Maternal and fetal outome in pre-eclampsia in a secondary care hospital in south India. J family Med Prim Care. (2015); 4(2): 257-260

[25] Obed SA and Patience A. Birth weight and ponderal index in Pre-eclampsia: a comparative study. Ghana Med J. (2006);40(1): 8-13 